\title{
THE MECHANISM OF MEMBRANE FORMATION AND OTHER EARLY CHANGES IN DEVELOPING SEA- URCHINS' EGGS AS BEARING ON THE PROBLEM OF ARTIFICIAL PARTHENOGENESIS
}

\section{E. NEWTON HARVEY \\ Columbia University \\ With Two Figures}

The first visible change occurring in many eggs af ter the en trance of a spermatozoön is the appearance, at the periphery of the egg, of a fertilization membrane. Although observed and discussed by many authors, very little experimental work has been done on the mechanism of its formation. Yet such an investigation may give a clue to the nature of the change initiating development.

This summer (I909) a study of membrane formation in Echinoderm eggs was undertaken. The experimental work was performed in part at the Biological Laboratory of the Carnegie Institution at Tortugas, Florida, and in part at the Marine Biological Laboratory at Woods Hole, Massachusetts. I wish to express my thanks to Dr. Ralph Lillie for the use of some reagents and to the Wistar Institute of Anatomy for a table at the latter station. I am also indebted to Dr. T. H. Morgan for very kindly criticising this paper.

The forms experimented on at Tortugas were Toxopneustes variegatus and to a less extent Hipponoë esculenta. At Woods Hole Arbacia punctula ta was used.

I shall discuss the early changes taking place in developing eggs under seven heads, viz:

I The efficiency of acetic acid in forming membranes at different temperatures.

2 The mechanism of membrane ${ }^{1}$ formation.

1 Unless otherwise stated, by membrane, the fertilization or vitelline membrane is meant. The surface film or plasma membrane of the egg is spoken of as the egg membrane. The two have very different properties both chemical and physical. 
3 The chemical nature of the membrane.

4 The migration of the pigment granules of Arbacia eggs.

5 Loss of pigment in Arbacia eggs.

6 Surface tension changes in fertilized and unfertilized eggs.

7 The action of development-starting substances in general.

I. THE EFFICIENCY OF ACETIC ACID IN FORMING MEMBRANES AT DIFFERENT TEMPERATURES

A well known method of determining whether a given process occurring in organisms is chemical or physical in nature, is to compare its temperature coefficient with the temperature coefficients of various known physical or chemical phenomena. In this way it has been shown that the rates of increase of the heart beat, conduction of the nerve impulse and many other organic processes are due to chemical processes since they are accelerated to the same degree by a rise of temperature as is the velocity of chemical reaction. The latter are distinguished from the great majority of physical processes, in that they are affected enormously by a rise in temperature. Chemical reactions proceed two to three times more rapidly with every $10^{\circ}$ rise in temperature. The same method may be used to see whether the action of a given substance is chemical or physical in nature.

My object in studying the effectiveness of acetic acid at different temperatures was primarily to test Loeb's hypothesis, that the reason the fatty acids are the most efficient acids in calling forth membrane formation is because of their property of dissolving lecithin and other lipoids. Solution is a physical process. The solubilities of most substances are not greatly affected by temperature. Unfortunately the exceptions to the above rule are mostly exhibited by fatty substances. As nothing is known of the solubility of lecithin in acetic acid at different tempera tures, a definite answer as to the action of acetic acid on the eggs cannot be given. Certain other possible actions, however, are excluded and certain others included by my results. These will be discussed after giving the results. 
The experiments were performed on the eggs of Toxopneutes variegatus. Perfectly normal membranes may be produced on returning to sea-water after the acid treatment. With Hipponoë the membranes formed after treatment with acetic acid are very close to the egg and almost invisible with the low power, except on slightly high focus when they appear separated from the egg surface by a very fine clear ring. This is not apparent in the untreated eggs, and in those eggs which have not responded to the treatment.

In all experiments the usual precautions against contamination with spermwere taken. About 2 cc. of sea-water, densely crowded with eggs, was pipetted to IOO cc. of the acid sea-water at the proper temperature. The eggs were then removed from the solutions at in tervals to sea-water at $29^{\circ} \mathrm{C}$. (the normal summer temperature of the water at Tortugas) and examined for membrane formation. The temperatures given were readings taken at the beginning and end of the experiment. Controls were always kept.

\section{EXPERIMENT I}

Fune 30, 1909. Eggs taken 4.45 p.m.

21 $\mathrm{ccc} \cdot \frac{\mathrm{N}}{10}$ acetic acid to $50 \mathrm{cc}$. sea-water.

\begin{tabular}{|c|c|c|c|c|c|c|c|c|}
\hline \multirow{2}{*}{ TEMPERATURE. } & & & \multicolumn{6}{|c|}{ TIME IN MINUTES AFTER 5.05 P. M, } \\
\hline & 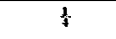 & $\frac{1}{2}$ & I & 2 & 3 & 4 & 6 & 8 \\
\hline $16^{\circ}-19^{\circ} \mathrm{C} \ldots \ldots \ldots$ & none & none & very few & $50 \%$ & $50 \%$ & $75 \%$ & $\infty \%$ & $100 \%$ \\
\hline $26^{\circ}-28^{\circ} \mathrm{C} \ldots \ldots \ldots$ & none & none & occasional & ery few & none & $65 \%$ & $10 \%$ & none \\
\hline $34^{\circ}-3^{6^{\circ}} \mathrm{C} \ldots \ldots \ldots$ & occasional & $50 \%$ & $50 \%$ & $10 \%$ & occasional & none & none & none \\
\hline
\end{tabular}

EXPERIMENT II

Fuly I, 1900. Eggstaken 7.30 a.m.

3 cc. $\frac{\mathrm{N}}{1 \mathrm{n}} \mathrm{CH}_{3} \mathrm{COOH}$ to $50 \mathrm{cc}$. sea-water.

\begin{tabular}{|c|c|c|c|c|c|c|c|c|c|}
\hline & \multicolumn{9}{|c|}{ TIME IN MiNUTES AFTER 8.15 A. M. } \\
\hline & $\frac{1}{4}$ & $\frac{1}{2}$ & I & $I^{\frac{1}{2}}$ & 2 & 3 & 4 & 6 & 8 \\
\hline $11^{\circ}-16^{\circ} \mathrm{C} \ldots \ldots$ & none & none & none & & occasional & occasional & $50 \%$ & a few & a few \\
\hline $19^{\circ}-20^{\circ} \mathrm{C} \ldots \ldots$ & none & none & occasional & & $30 \%$ & $70 \%$ & $30 \%$ & a few & a few \\
\hline $29^{\circ}-30^{\circ} \mathrm{C} \ldots \ldots$ & $50 \%$ & $70 \%$ & $90 \%$ & $100 \%$ & $90 \%$ & $40 \%$ & none & none & none \\
\hline
\end{tabular}




\begin{tabular}{|c|c|c|c|c|c|c|}
\hline $1,20 \mathrm{P}, \mathrm{M}$ & I cc. & $1 \frac{1}{2}$ & 2 & 3 & 4 & 6 \\
\hline $\begin{array}{l}1 / \min \ldots \ldots \ldots \ldots \ldots \ldots \ldots \ldots \ldots \ldots \ldots \ldots \ldots \ldots \ldots \\
3 \min \ldots \ldots \ldots \ldots \ldots \ldots \ldots \ldots\end{array}$ & $\begin{array}{l}\text { none } \\
\text { occasional } \\
\text { occasional }\end{array}$ & $\begin{array}{c}\text { none } \\
\text { occasional } \\
10 \%\end{array}$ & $\begin{array}{l}25 \% \\
70 \% \\
90 \%\end{array}$ & $\begin{array}{l}45 \% \\
* \\
90 \%\end{array}$ & $\begin{array}{l}5 \% \% \\
90 \% \\
90 \%\end{array}$ & $\begin{array}{l}80 \% \\
60 \% \\
\text { none: }\end{array}$ \\
\hline
\end{tabular}

Temperature $34^{\circ}-33^{\circ} \mathrm{C}$.

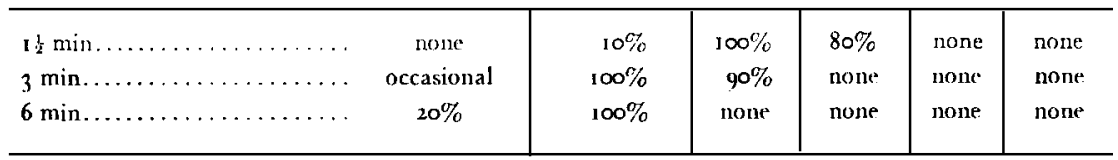

*Missed.

The above tables may be simplified as follows:

EXPERIMENT I

Uptimum time of exposure

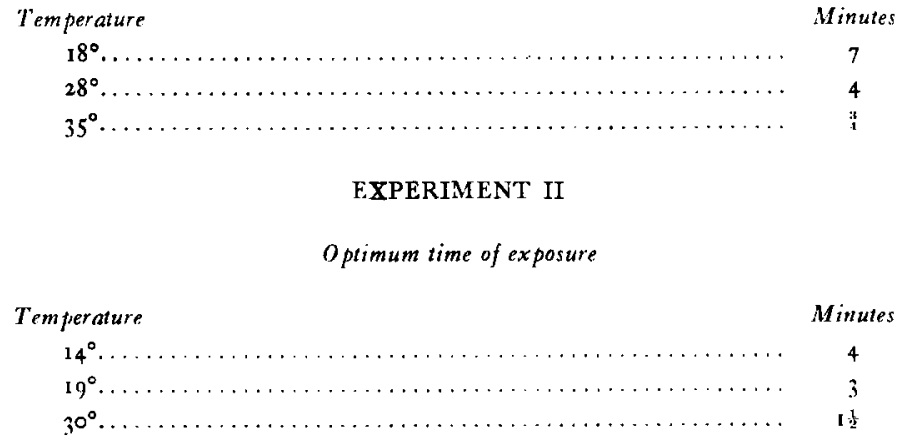

There is about a halving of the time of exposure required for a rise of $10^{\circ} \mathrm{C}$. When the optimum concentrations instead of the optimum times are compared as in Experiment III the following result is obtained: 


\begin{tabular}{|c|c|c|}
\hline TIME OF EXPOSURE & $\begin{array}{c}\text { TEMPERA- } \\
\text { ture }\end{array}$ & OPTIMUM CONC, OF ACID \\
\hline $\begin{array}{l}1 \frac{1}{2} \text { minutes..... } \\
3 \text { minutes..... } \\
6 \text { minutes...... }\end{array}$ & 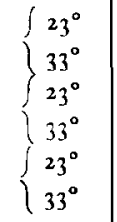 & 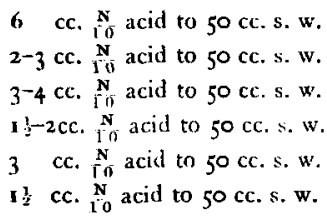 \\
\hline
\end{tabular}

Both the optimum-time and optimum-concentration figures show a large increase in the efficiency of acetic acid with a rise of temperature of $10^{\circ} \mathrm{C}$. Expressed in terms of a temperaturecoefficient $(Q)_{10}$ the increase amoun ts to a doubling, thus:

$$
Q_{10}=\frac{K t}{K_{\mathrm{t}+10}}=2
$$

in which $Q_{10}$ is the ratio of a constant at a temperature $t$ degrees, to a constant at $t+10^{\circ} \mathrm{C}$. The very marked efficiency at $36^{\circ}$ may be an additive effect as high temperatures are known to cause membrane formation in both sea-urchins and starfish eggs. I did not succeed in producing membranes on Toxopneustes eggs by exposure to sea-water at those temperatures and for the times used with the acid treatment.

What changes might the dilute acetic acid bring about in the egg of a sea-urchin which would result in the formation of a membrane? The chief possibilities are three. It might:

I Dissolve out the lipoids at the periphery.

2 Change the surface tension of the egg directly, in that the composition of the medium about the egg is altered. Instead of egg protoplasm-sea-water, we have egg protoplasm-acid seawater.

3 Combine with some of the egg proteids.

The first possibility has already been discussed.

The surface tension between two phases is only very slightly influenced by temperature. For the same reason diffusion rate and degree of dissociation of $\mathrm{CH}_{3} \mathrm{COOH}$ would be negligible factors. 
There remains only the most probable action, an actual combination of the acid with some of the egg proteids, the rate of formation of this compound varying with the temperature as do other reactions $\left(Q_{10}=2-3\right)$.

Greeley's ${ }^{2}$ results with $\mathrm{HCl}$ also bear out this conclusion

Assuming that the acetic acid actually takes part in some reaction ${ }^{3}$ in the egg, which is it? Is the membrane-for there is now ample evidence (to be discussed below) to show that the membrane is not present before fertilization--a result of the union of $\mathrm{CH}_{3} \mathrm{COOH}$ with some egg substance? It can bedefinitely said that this is not the case. The many substances which will produce membranes are so diverse, chemically, that it is inconceivable they should all combine to form the same substance (membrane) or even by their presence bring about its formation. It is obvious that heat and mechanical agitation could not act in this way. The membrane is all ready to be formed yet is prevented from so doing by something. It forms only another example of the so-called "stimulus reactions," which have been compared to the setting off of a charge of gunpowder by a spark. The change which "sets off" the membrane formation as well as the reactions in to which $I$ believe the acetic acid enters will be discussed in the second division of this paper.

\section{MECHANISM OF MEMBRANE FORMATION}

I shall first propose an explanation, of how a membrane may be conceived to form about a system of interacting substances, (as an egg), and then discuss somewhat more fully various facts connected with its actual production.

As observed in the living egg, almost immediately ( $1 \frac{1}{2}$ to 3 minutes) after the addition of sperm the membrane substance becomes separated from the egg surface by spaces. These spaces fill with a fluid, unite and enlarge, thus pushing out the membrane

${ }^{2}$ Greeley: A. W. Biol. Bull., iv, 1902-3, p. 124. Greeley did not interpret his results with reference to chemical action.

${ }^{3}$ Reaction is used throughout this paper in the same sense as in chemistry. 
some little distance. Two separate events take place, the formation of the membrane, and its separation from the egg.

\section{Mechanism}

In order to simplify conditions as much as possible let us consider what would occur under certain conditions in an egg cell (Fig. 2) in which everything has been removed except those substances directly connected with the membrane reaction. Its

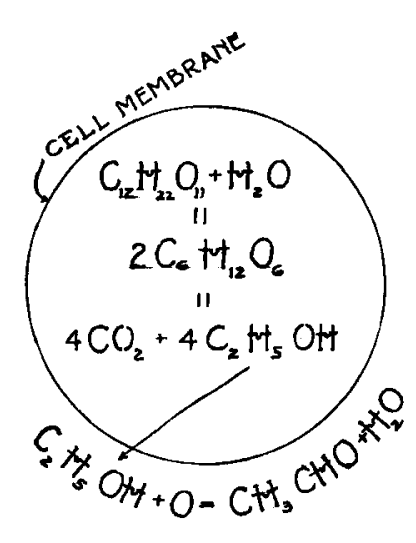

1

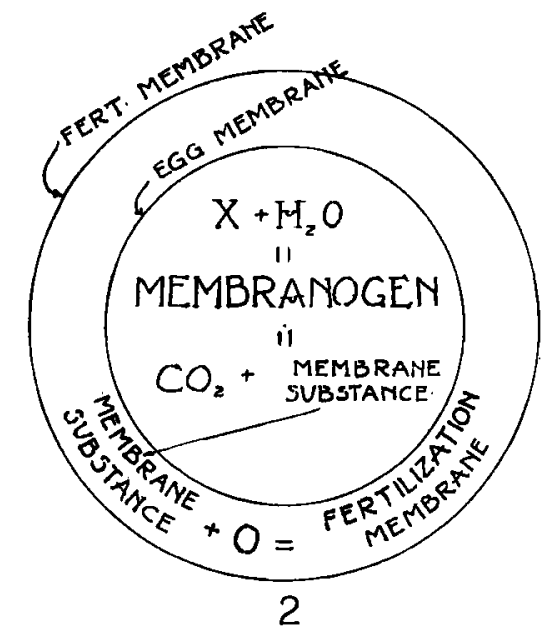

Figs 1 and 2.

inorganic analogue would be represented by an hypothetical cell (Fig. r) containing cane sugar and appropriate enzymes.

The ractions indicated above will proceed until all the substances are present in definite proportions. Equilibrium is then attained. The egg (cell) membrane is impermeable to the contained substances and also to the salts of sea-water. This represents the condition in the mature sea urchin egg. Suppose now a momentary change of permeability occurs so that $\mathrm{CO}_{2}+$ membrane substance $\left(\mathrm{CO}_{2}+\mathrm{C}_{2} \mathrm{H}_{5} \mathrm{OH}\right)$ may pass out of the system. This upsets the equilibrium and the reactions proceed in the direc- 
tion of the arrows until checked by a second accumulation of reaction products and equilibrium is again attained.

The rrembrane substance, in contact with sea-water, hardens, (presurrably an oxidation and comparable to the hardening of silk in the air) thus forming a film. Some proteid substance formed just behind the fertilization membrane (possibly a small amount of the membranogen diffuses out during increased permeability) would absorb sea-water and push the membrane out.

A second increase in permeability would result in a repetition of the process with the formation of a second membrane.

The principle of Gibbs as applied by Metcalf 4 may help in understanding how this reaction can proceed so readily at the cell boundary. If, in a solution, a reaction occurs, one of the products of which lowers the surface tension of the mixture, the commencing of the reaction will be favored at the surface and the products will collect at the surface.

The rôle of the acetic acid in membrane formation would be the increasing of the permeability of the egg membrane. This is presumably brought about by a combination of $\mathrm{CH}_{3} \mathrm{COOH}$ with some of the surface proteids, a change with which increased permeability is assumed to be connected. At the end of this paper I shall give some further general evidence for the permeability theory..$^{5}$

The actual process of membrane formation as observed under the microscope reveals nothing contrary to the above theory. Herbst $^{6}$ in I 893 cut sections of eggs, fixed at in tervals from immediately after fertilization till the pushing out of the membrane. $\mathrm{He}$ describes the clear "Protoplasmasaum" becoming plainly thicker just before a portion of it becomes lifted off and he interpreted this to indicate a secretion. It is not very resistant first but later becomes quite firm. The pushing out from the

\footnotetext{
4 Metcalf: Zeit. Physic. Chem. 52 p., 1905; also Höber, Physikalische Chemie d. Zelle und Gewebe, 2 cd. Leipzig, 1906, p. zo9.

SSe my preliminary report (Year-book, Carnegie Inst., Washington, no, 8, pp. 119. 1909), and Science, n. s., $\mathbf{x x}$, p. 776, 1909, also similar evidence by Lillie, R. S. (Biol. Bull., xvii, p. 202, 1909). and McClendon (Science, n. s., xxx, P. 454, 1909).

6 Biol. Centralb., 13, 1893 , p. 14.
} 
egg is due to "eine gallertartige Substanz, welche durch von aussen aufgenommenes Wasser aufquillt." Loeb7 has recently expressed the opinion that an "Eiweisskörper" or lipoid is the substance concerned in the absorption of sea-water and resultant separation of the membrane.

I had come to similar conclusion this summer before having read Loeb's or Herbst's papers. The facts are as follows: The fluid between the egg and fertiliza tion membrane has too great a volume to have come from the egg without a corresponding diminution in size. It must be chiefly sea-wa ter. It at least con tains considerable chlorides (as shown by precipitation with $\mathrm{AgNO}^{3}$ ). The fertilization membrane is very freely permeable to the salts of sea-water, relatively impermeable to sugar and proteids. A small concentration of a sugar or proteid (even though its osmotic pressure were far less than that of sea-water) would be capab'e of absorbing sea-water through a membrane perfectly permeably to sea-water.

\section{Double Membranes}

I have already mentioned the result we should expect in a hypothetical sugar cell if the permeability of its membrane should be a second time momentarily increased, namely, a second escape of the reaction product. In the egg a second membrane should be formed by substances causing a second increase of permeability. This actually occurs. Tennen $t^{8}$ has recorded a second membrane formed by sperm on starfish eggs which had previously been treated with $\mathrm{CO}_{2}$ and formed membranes. I was unable to get the above result in sea-urchin (Toxopneustes) eggs treated with $\mathrm{CH}^{3} \mathrm{COOH}$ followed by the addition of sperm. Only those eggs which had been subjected to the acid treatment too short a t me to form membranes could be fertilized. They segmented normally. The spermatozoa were apparently unable to pass membranes formed by acid.

'Loib, J.: Arch. Entwm., xxvi, I 908, p. 82.

"Tement: Journ. Exp. Zoöl., 31, 1906, p. $53^{8}$. 
Chloroform saturated sea-water causes membrane formation in a large per cent of Toxopneustes eggs. If the eggs have been fertilized first, beautiful examples of double membranes can be obtained by after treatment with $\mathrm{CHCl}_{3}$ saturated sea-water. ${ }^{9}$ The second membrane (due to $\mathrm{CHCl}_{3}$ ) is just as distinct as the true fertilization membrane and lies half way between it and the egg surface. These eggs are also more normal looking than unfertilized eggs subjected to $\mathrm{CHCl}_{3}$ sea-water treatment as the cytolytic changes caused by the $\mathrm{CHCl}_{3}$ do not take place so rapidly on eggs with membranes already formed, probably because the membrane offers some resistance to its ready entrance. This second membrane can be formed on eggs which are in the two cell stage and also up to early blastulæ.

In the two cell stage it is as distinct as in undivided eggs and surround each of the blastomeres. The greater the number of blastomeres the less distinct does it become and the more closely does it surround each cell. The space between it and the cell surface also becomes less transparent as if filled with some other constituents of the blastomeres which have diffused out. The fact that membranes can be produced so late in segmentation stages indicates a considerable similarity in the constitution of the egg during early cleavage stages. ${ }^{10}$

An extremely fine and delicate second membrane is formed on fertilized Arbacia eggs placed in four times concentrated seawater as also on the evaporation of the sea-water on a slide. This is accompanied by loss of pigment and other constituents of the eggs.

Attempts to produce secondary membranes in fertilized Toxopneustes eggs with $\mathrm{CH}_{3} \mathrm{COOH}$ failed, even though they were treated long enough to bring about the characteristic effects of over treatment.

\footnotetext{
${ }^{9}$ Herbst had already performed this experiment. Loc. cit.

${ }^{10}$ On examining the literature I find that Loeb (Arch. Entwm. 23, 19c7. p. 479) has alreaty recorded membranes formed on individual blastomeres. In one case 2-4 cell stages were obtained by $\mathrm{CaCl}_{2}$ treatment ( $50 \mathrm{cc} \cdot \frac{3}{\mathrm{~B}} m \mathrm{CaCl}_{2}+1.6 \mathrm{cc} . \stackrel{\mathrm{N}}{\mathrm{N}} \mathrm{NaOH}$ ). In another case $2-16$ cells were produced by hypertonic treatment. In both cases when sperm was added the individual blastomeres became entirely surrounded by a membrane and dwarf gastrulae resulted from their further development.
} 


\section{Different $T$ ypes of Membranes}

Loeb ${ }^{11}$ has cited several instances of development without membrane formation in sea urchins and R. Lillie. ${ }^{12}$ has mentioned such a case in starfish. The best known case is presented by development after trea tment with hypertonic sea-water. I have repeated this experiment of Loeb's (using $100 \mathrm{cc}$. sea-water $+\mathrm{I}_{5} \mathrm{cc} .2 \frac{1}{2} \mathrm{~m}$ $\mathrm{KCl}$ for I hour 20 minutes) and find that there are membranes formed on these eggs exactly like those formed on Hipponoe eggs treated with $\mathrm{CH}_{3} \mathrm{COOH}$ already mentioned. They are very close fitting and might easily escape notice. Membranes which push out only very slightly from the egg surface may be produced by sperm fertilization at high and at low temperatures ( $15^{\circ}$ to $20^{\circ} \mathrm{C}$. with Toxopneustes at Tortugas, and $32^{\circ} \mathrm{C}$. with Arbacia at Woods Hole). The eggs are mixed with the sperm for about one-half minute and then placed in the sea-water at the proper temperature. Cases of development without membrane formation seem to be rather cases of development without pushing out of the membrane.

Another type of membrane is obtained by allowing eggs to stand at room temperature for 28 hours. When sperm is added practically all the eggs become surrounded by a thick membrane adhering to the egg surface closely. When the egg divides this surrounds each of the blastomeres, which become quite spherical. Similar membranes are formed by sperm fertilized eggs in $\mathrm{Ca}$ free sea-water.

That the fertilization membrane is not present as a surface film in unfertilized eggs which is later pushed out is shown by the fact that unfertilized eggs dissolve completely in concentra ted $\mathrm{H}_{2} \mathrm{SO}_{4}$ while fertilized eggs dissolve all but the membranes.

"Loeb. J. (1) On fertilizing with sperm after $4^{8}$ hours standing in sterilized sea-water. Pflügers Archiv. 93, p. 59, 1903. (2) By hypertonic sea-water. Univ. Calif. Pub. Phys., ii. p. 83, 1905. (3) After treatment with pig serum some eggs form no membranes. These may segment and develop into larvae. Arch. f. d. ges. Physiol. 124, p. 250, 1908. (4) Some eggs of Asterina form no membranes after acid treatment, yet develop into small blastula, Univ. Calif. Pub. Phys. ii. p. 153, 1905.

12 R. Lillie. After 20 hours in $\frac{M}{20 \sigma}$ KCN eggs are warmed. No membranes form yet segmentation takes place. Journ. Exp. Zoöl. v, p. ${ }_{386,}$, 908. 
III. CHEMICAI, NATURE OF 'IHE MEMBRANE

Fxperiments were also undertaken to determine the composition of the fertilization membrane. Arbacia eggs were used.

Their membranes are insoluble in $m \mathrm{KOH}$ and $\mathrm{NaOH}$ even on short boiling, al though the eggs become en tirely colorless only a few granules being visible. On prolonged boiling and evaporation when the strength of the alkali must approach $2 \frac{1}{2} \mathrm{~m}$, the membranes dissolve or at least become so broken up as to be invisible.

In cold concentrated $\mathrm{H}_{2} \mathrm{SO}_{4}$, the membrane is insoluble while the egg substance first chars reddish brown, later becoming en tirely invisible so that only the spherical fertilization membrane is apparent. Unfertilized eggs without membranes dissolve entirely in concentrated $\mathrm{H}_{2} \mathrm{SO}_{4}$.

In concentrated $\mathrm{HCl}$ there is no solution of the membrane. The egg contents become a clear shrunken granular mass. Eggs in the two cell stage show the division between the blastomeres as a clear line. Concentrated $\mathrm{HNO}_{3}, \mathrm{NH}_{4} \mathrm{OH}$ and glacial acetic acid act like $\mathrm{HCl}$.

I was unable to demonstrate any proteid in the membrane $b y$ the xanthoproteic test although this may be due to its thinness. At any rate the membrane appeared colorless while the egg contents. were turned a bright yellow.

Lillie ${ }^{13}$ has recently expressed the opinion that the fertilization membrane is "a paptogen membrane consisting mainly of protein material." Such a membrane would be much more delicate and easily ruptured than the fertilization membrane is. Besides there appears to be little if any protein in it as shown by its insolubility in pepsin $\mathrm{HCl}$, caustic alkalies and concentrated $\mathrm{H}_{2} \mathrm{SO}_{4}$. It may be compared to the cellulose layers formed about plant cells after division, or to the chitinous skeleton formed in insects by the hypodermal cells. In composition it is probably one of the albuminoids.

${ }_{13}^{13}$ Lillie, R.: Biol. Bull., xvii, pp. 202. 1909. 
SUMMARY

The essential points brought out in the preceding pages may be summarized as follows:

The action of acids in producing membranes on unfertilized sea-urchin eggs is due to their combination with some substance in the egg but the membrane is not the product of this combination.

In composition the membrane is probably an albuminoid. It is not present as such before fertiliza tion.

The essential condition for its formation is an increased permeability of the egg surface for a membrane substance which passes out and hardens to the membrane in contact with seawater (a secretion). Double membranes may be explained on the above theory.

Several types of membrane may be produced under different conditions and it is probable that the secretion of the membrane substance always takes place although it may remain close to the egg surface.

IV. MIGRATION OF THE PIGMENT GRANUIES OF ARBACIA EgGS

The second visible change which takes place after fertilization in Arbacia eggs is the migration of the red pigment granules to the surface. In the mature unfertilized and the immature eggs they lie distributed throughout the cytoplasm. This change takes place within ten minutes after fertilization and invariably whenever membrane formation takes place, no matter by what means brought about, whether by acid, by osmotic treatment or by sperm. It is thus associated with membrane formation and may be explained as follows: Most small particles suspended in fluid media become negatively charged and there is additional evidence that these pigment containing bodies are so charged. Lillie $^{14}$ has brought together evidence that the centrosomes are 
negative regions. When the micromeres are formed the pigment is prevented from entering them by the large and prominent asters, then present. Even when cut off from the pigmented area of cen trifuged eggs these cells are rela tively free of pigment. ${ }^{15}$ The granules are thus repelled by the centrosomes. If an increase of permeability is the change initiating the development of an unfertilized egg the same potential differences (between exterior and interior, and different regions of the cell) might be expected that takes place in muscles during stimulation. These potential differences are quite general in the functioning of various tissues (nerves, glands, sensitive plants, etc). Their origin is most easily accounted for by variations in differential permeability of the cell to anions and cations. ${ }^{16}$ Lillie $^{17}$ has discussed this theoretically in a recent paper. Without going in to details it may be said that "with the appearance of an increased permeability the peripheral regions of the protoplasm must become, for a time at least until the potentials are equalized, positive rela tive to the interior." Such pigment granules if negatively charged would be drawn by the electrostatic attraction of the now positive egg surface, to the surface, providing of course, the potential difference were high enough. A calculation (by Lillie) of this based on the observed changes in muscle cells has given a value of 14 volts per $\mathrm{cm}$. This would be ample to account for the migration actually observed in Arbacia eggs.

The orientation of small particles with relation to the asters occurs in other eggs. Fischel ${ }^{18}$ in staining sea-urchin eggs with intra-vitam dyes noted a migration of particles stained with neutral red, toward the nucleus and aster, the formation of an ellipse about the spindle-figure and a ring about each daughter nucleus where the cell divides, and finally, during the resting stage, even redistribution throughout the cytoplasm. This process is repeated during each cell division.

\footnotetext{
${ }^{15}$ Lyon, E. P.: Arch. Entwm., 23, P. 67.1907.

${ }^{16}$ See Bernstein, Arch. f. d. ges. Physiol, 1902, xcii, and Brunings, id. xcviii, and c. 1903.

${ }^{17}$ Lille, R.9: Biol. Bull. xvii, p. 207-208, r 909.

18 Fischel, A.: Anat. Hefte, 37, p. 863, 1899, also Arch. Entwm., xxii, p. 526, 1906.
} 
Since the pigment of Arbacia eggs is soluble in water it follows that the membrane of the chromatophore granules must be impermeable to the contained pigment, otherwise it would diffuse through the cytoplasm and out of the eggs (providing the egg membrane were also permeable to it). If the eggs are heated diffusion of the pigment in to the sea-water takes place, showing an increase in permeability in both the chromatophore and plasma membranes. I have never noticed a permeability (to pigment) of the former independent of the latter. There is also evidence that the impermeability of the granule membrane is dependent on the plasma membrane. If unfertilized eggs are crushed slightly under a cover glass, part of their contents will flow out in to the sea-water and round up. The colored granules which have been pressed out immediately lose their pigment while those within the original fraction still retain it. I do not think this can be due to crushing because the bodies are so small. There is also a difference in the optical properties of the surface newly formed about the extruded protoplasm as compared with the old.

The same phenomenon is observed when eggs are placed in hypotonic sea-water (sea-water one third, distilled water twothirds. The eggs swell and their surface layer becomes indistinct.

When this occurs the pigment immediately disappears from granules and diffuses throughout the cytoplasm. At the same time in many eggs a thin irregular membrane separates.

A loss of the pigment, which becomes a yellow-red color, occurs in four times concentrated (by evaporation) sea-water ${ }^{19}$. The same solution occurs in $\mathrm{CH}_{3} \mathrm{COOH}$ in concen trations grea ter than those required to produce membranes. This index of determining permeability changes has been used by Lillie ${ }^{20}$ working on muscle cells. Pure isotonic solutions of electrolytes which cause

\footnotetext{
${ }^{19}$ See Loeb's description of this in Strongylocentrotus U. Calif. Pub. Physiol. ii, pp. 73-81, 1905.
}

${ }^{20}$ Lillie, R.: Am. Journ. Physiol. xxiv, p. 14, 1909, and id. p. 459. 
contraction in the muscles, bring about a loss of pigment in the cells of the same organism, Arenicola larva. McClendon ${ }^{21}$ mentions that the parthenogenetic agents which he has used bring about a loss of pigment in sufficient concentration, and Loeb ${ }^{22}$ had already emphasized the cytolytic nature of membrane forming substances although interpreting it in a different way.

VI. SURFACE TENSION CHANGES IN FERTILIZED AND UNFERTILIZED EGGS

In the same paper ${ }^{23}$ which was cited in discussing the cause of the movement of the pigment granules of Arbacia eggs to the surface, Lillie has pointed out the relation which should exist between changes of permeability (accompanied by ionic interchange) and the surface tension of the membrane in question. An increase of permeability should be accompanied by an increase in surface tension (in as much as the surface tension of a film is greatest when the potential difference between its two sides is least). This actually does take place in Echinoderm eggs. Eggs from the same females are of ten somewhat irregular in shape, frequently being elongated, twice as long as wide. Sometimes 40 per cent of Arbacia eggs are in this condition and I have seen practically all the mature eggs of Toxopneustes irregular just after shedding. It is hard to realize that such small bodies can exhibit the shapes they do especially if they are compared with other fluid systems of the same size, as oil droplets, which maintain their spherical form through their high surface tension. If such irregular eggs are fertilized with sperm or treated with $\mathrm{CH}_{3} \mathrm{COOH}$ there is an immediate change. They all become spherical, indicating an increase of surface tension. The rounding of eggs on fertilization takes place quite generally. Whether this is actually due to a change in potential difference resulting from increased permeability is not so certain but it is significant that the change occurs just after the entrance of a spermatozoön or after treatment with acid sea-water.

21 Science, n. s. xx8, p. 454, 1909.

${ }^{22}$ Loeb, J.: Arch, f. d. ges. Physiol. 122, p. 196, 1908.

2.) Lillie, R.: Loc. cit., p. 204. 
Sea urchin eggs (Arbacia and Toxopneustes) also round up on standing for some time in sea-water thus indicating an increase in surface tension. They also become fertilizable by foreign sperm on standing ${ }^{24}$ (ca. 6 hrs.) or by treatment with an acid or alkali (in concentrations too weak to cause membrane formation.) It appears as if the change undergone by the eggs on standing were in the direction of increased permeability and that the egg must start toward development in order to be fertilized by foreign sperm. Some eggs do undergo division on standing but it is probable that accessory factors are responsible for this.

In order to determine further the nature of the change taking place in mature unfertilized sea-urchin eggs on standing in seawater, and especially if this change were in the direction of increased permeability, I tried if any less acid were required to cause membrane formation six hours after shedding. At this time the eggs of Toxopneustes become fertilizable by foreign sperm. The following table is a typical result:

$$
\text { 7uly 14, toog. Eggs taken 12.30 p.m. Temp. } 33^{\circ} . t 034^{\circ} \text {. }
$$

CONCENTRATION-CC. ACID To 50 CC. SEA-WATER

\begin{tabular}{|c|c|c|c|c|c|c|}
\hline & $1 \mathrm{cc}$. & i. 5 & 2 & 3 & 4 & 6 \\
\hline $\begin{array}{l}\frac{3}{4} \text { hour after taking } \\
\quad 1 \frac{1}{2} \text { minutes............ } \\
\quad 3 \ldots \ldots \ldots \ldots \ldots \ldots \ldots\end{array}$ & $\begin{array}{l}\text { none } \\
\text { very }\end{array}$ & $\begin{array}{r}10 \% \\
100 \%\end{array}$ & $\begin{array}{r}100 \% \\
90 \%\end{array}$ & $\begin{array}{l}80 \% \\
\text { none }\end{array}$ & $\begin{array}{l}\text { none } \\
\text { none }\end{array}$ & $\begin{array}{l}\text { none } \\
\text { none }\end{array}$ \\
\hline 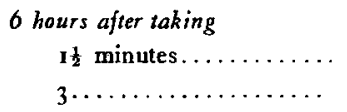 & $\begin{array}{c}\text { lone } \\
\text { sery few }\end{array}$ & $\begin{array}{c}\text { very few } \\
30 \%\end{array}$ & $\begin{array}{r}100 \% \\
90 \%\end{array}$ & $\begin{array}{c}80 \% \\
\text { very few }\end{array}$ & $\begin{array}{l}\text { none } \\
\text { none }\end{array}$ & $\begin{array}{l}\text { none } \\
\text { none }\end{array}$ \\
\hline
\end{tabular}

Another experiment like the above gave a similar result, the optimum treatment, both as regards time and concentration, about coinciding three-fourths and $5 \frac{3}{4}$ hours after taking the eggs. If any, a very slightly longer treatment appears more favorable. Certainly the eggs require no less acid to cause membranes to form after standing for six hours. In the above experiment the per cent of eggs which could be caused to form membranes was

${ }^{24}$ See Tennent, Biol. Bull. xv, p. 127, 1908.

JOURNAL OF EXPERIMENTAL. Zö̈LOGY, vol. 8, No. 4 . 
less in the lot which had stood. This is also the case when eggs are fertilized with their own sperm. I tried this experiment with Hipponoë with the same result.

Apparently the increase in surface tension on standing is not connec ted with an increase of permeability as I believe the increase after fertilization to be. The increase in surface tension may account for the entering of starfish sperm which could not enter immediately after shedding of the eggs, for Loeb ${ }^{15}$ has expressed the opinion that the surface tension of the egg and sperm are the determining factors in the entrance of the spermatozoön. As the sea-urchin egg stands a decreasing per cent of its own sperm becomes capable of entrance while an increasing per cent of foreign sperm may enter.

VII. ACTION OF DEVELOPMENT-STARTING SUBSTANCES IN GENERAL

Throughout this paper a momentary increase in permeability of the egg membranes has been mentioned as the fundamental change underlying membrane formation and the initiation of development. Eggs in which no membranes are formed are excited to development by the same means as eggs which do secrete a membrane, so that this increase of permeability is probably a change occurring after the entrance of a spermatozoön in all eggs. A consideration of the various parthenogenetic agents bears this out.

A classification of the present known means of causing eggs to develop is as follows:

I Hypertonic solutions (with an $\mathrm{OH}$ ion concentration 10-6). Raising the osmotic pressure of the medium by electrolytes or non-electrolytes or evaporated sea-water. The most universal method for Echinoderms, Annelids, Molluscs and Vertebrates.

2 Hypotonic solutions and distilled water (Asterias and Arbacia), Shucking.

3 Mechanical agitation (Annelids and Star-fish).

4 Temperature changes (Echinoderms).

${ }^{25}$ Loeb.: Dynamics of Living Matter, p. 163. 
1 Short exposures to high temperatures.

2 Long exposures to low temperatures. ${ }^{26}$

5 Electrical shocks.

I Charging eggs (Strongylocentrotus) Delage.

2 Induced shocks (Arbacia) McClendon.

3 Constant current (Asterias) (?) Shucking.

6 Chemical reagents.

I Specific actions-K, $\mathrm{Mg} ; \mathrm{Mn} \mathrm{Ni}$ and Co. (?) (Delage)

2 Alkaloids and glucosides (saponin, solanin, pilocarpin, strychnin, quinin, hyocyamin, nicotin.)

3 Tannin and re'ated substances.

4 Fat solvents (ether, chloroform, benzol, alcohol).

5 Bile salts ( $N a$ taurocholate and glycocholate).

6 Blood sera (of rabbit, pig, ox, and certain worms).

7 Acids and alkalies.

7 Absence of oxygen (weak $\mathrm{CNK}$ and O-free sea-water). ${ }^{26}$

A glance at the above classification will show the general similarity in the means of stimulating muscles and sensitive plans and of exciting unfertilized eggs to develop. They are both stimulus responses, and may be expected to show a common underlying cause conditioning the response. I have discussed this in a preliminary note in Science ${ }^{27}$ and quote from it: "A considerable mass of evidence now exists, especially emphasized ir: recent papers of Ralph Lillie, ${ }^{28}$ that stimulation of muscles is effected by a momentary increase in the permeability of the muscle membrane to $\mathrm{CO}_{2}$ allowing its more ready escape during contraction. $\mathrm{CO}_{2}$ is the chief end product of the energy-yielding reaction on which contraction depends and its removal from the cell allows the reaction to proceed (during contraction) to a new equilibrium (of rest) when checked by a second accumulation

\footnotetext{
Absence of oxygen and low temperature as well as hypertonic solutions (in part) seem to act as correcting agents, setting the oxidations in the cgg on the right path to proper development, (Loeb), and as such do not come for discussion within the scope of this paper.

27 Science, n. s., xxs, p. 694, 1909.

28 Lillie, R. S.: Am. Journ. Physiol, xxii, p. 75, 1908; xxiv, p. 14, 1909; and xxiv, p. 459, I go9.
} 
of $\mathrm{CO}_{2}$. The increase of permeability on stimulation removes the condition which is preventing the contraction. The movements of sensitive plants can best be explained as due to an increase in permeability of the cell membranes relative to the turgor maintaining substances. The important point is that processes in general brought about by stimulation are connected with changes in permeability." Morgan expressed the situation clearly when he compared the means of causing development to a stimulus.

The best method of determining permeability changes is by the use of pigment con taining cells, such as red blood corpuscles. The escape of haemoglobin serves as an indicator of increased permeability. This process of haemolysis occurs frequently in cases of organic poisoning and is manifested in living animals by haemoglobinuria. In the laboratory loss of haemoglobin (from erythrocytes) can be brought about in various ways, by strongly hypertonic as well as by hypotonic solutions. Brahmachari ${ }^{29}$ regards the laking in hypotonic media to be due to some other cause than the actual rupture of the corpuscle by absorption of water. High (heat laking at $60^{\circ} \mathrm{C}$.) temperatures, condenser discharges, and a great variety of chemical substances also allow the haemoglobin to escape. Of the latter may be mentioned acids (especially fatty acids) and alkalies, glucosides and alkaloids (saponin, solanin, pilocarpin), tannin and related substances, fat solvents (chloroform, ether, alcohol, benzol), the bile salts ( $\mathrm{Na}$ glycocholate and taurocholate), soaps, haemolysins of foreign blood sera and of animal (cobra, spider, crotalus venom), plant (Amanita and Helvella) and bacterial poisons.so

The list given above coincides almost exactly with the list of chemical substances starting development. As yet there have been no experiments on the poisons mentioned but it is highly probable that reptile, fungus, and bacterial poisons will be found as efficient in causing development as Loeb has shown the bile

\footnotetext{
${ }^{29}$ Brahmachari, U. N.: Biochem. Journ. iv, p. 280 , 1909.

${ }^{30}$ For a discussion of means and substances causing haemolysis, see Stewart, G. N. Journ. of Pharmacology and Exp. Therapeutics, i, 1909, p. 49. Heinz, R..: Handbuch der experimentellen Pathologie u. Pharmakologie, Bd. i, p. 392, Jena, I9c4.
} 
salts, solanin and saponin to be. The specific ions may well increase the permeability of egg cells, for their action on other tissues is of this nature. In the alkali and alkaline earth metals this has been very clearly brought out by Lillie's work on Arenicola larvae, already mentioned.

It seems probable that the induced increase of permeability brings about the development of an egg for the same reason that the increase on stimulation brings about contraction in muscle cells, namely, by permitting, at the proper time, the escape of some reaction product which is preventing, by its accumulation, the further proceeding of reactions in the egg. This is one very important way in which chemical equilibria may be upset in fluid mixtures surrounded by membranes whose permeability may vary. The reaction product which escapes may be simply $\mathrm{CO}_{2}$, (as appears to be the case in muscles) or some more complex substance, (as the membrane substance) or both. A discussion of this with practically no experimental data would be useless, however.

The facts which indicate a momentary increase in permeability of the surface membrane, as the first change taking place in the development of an egg, may be summarized as follows: $:^{31}$

I The general similarity in the means of stimulating eggs to divide, and the means of stimulating muscles and sensitive plants. These may be broadly classified as chemical, mechanical, electrical, thermal, and osmotic.

2 The fact that the chemical substances which start parthenogenesis cause in other cells an increase in permeability (haemolysis of red blood corpuscles and loss of pigment in pigment bearing cells).

3 Evidence that stronger concentrations of development starting substances cause loss of pigment in pigmented eggs.

4 That a secretion is the first visible change occurring in many eggs.

5 That a migration of pigment-containing granules to the cell surface in Arbacia eggs is caused by a region of positive change 
at the surface resulting from ionic interchange accompanying increased permeability after membrane formation.

6 That an increase of surface tension, which must accompany a change of potential at the surface, is quite general in naked eggs after fertilization, as indicated by their rounding up when previously they had been irregular in outline. 